Granville-Grossman, K. (1971). In Recent Advances in Clinical Psychiatry, p. 12, Churchill, London.

Haefely, W., Hürlimann, A., and Thoenen, H. (1964). Helvetica Physiologica Acta, 22, 15.

Hammer, W., and Brodie, B. B. (1967). Journal of Pharmacology and Experimental Therapeutics, 157, 503.

Hammer, W., Ideström, C.-M., and Sjöqvist, F. (1967). In Antidepressant Drugs, ed. S. Garattini and M. N. G. Dukes, p. 301. Amsterdam, Excerpta Medica.

Møller-Nielsen, I. (1970). In The Neuroleptics. p. 68. ed. D. P. Bobon, P. A. J. Janssen, and J. Bobon. Basel, Karger.

Schildkraut, J. J., and Kety, S. S. (1967). Science, 156, 21.
Siegel, S. (1956). Nonparametric Statistics for the Behavioral Sciences. New York, McGraw-Hill.

Sigg, E. B., Soffer, L., and Gyermek, L. (1963). Journal of Pharmacology and Experimental Therapeutics, 142,13

Sjöqvist, F. et al., (1968). In Toxicity and Side Effects of Psychotropic Drugs, ed. S. B. de C. Baker, J. R. Boissier, and W. Koll, p. 246. Amsterdam, Excerpta Medica.

Sjöqvist, F., Hammer, W., Borgå, O., and Azarnoff, D. L. (1969). In Collegium Internationale Neuro-psychopharmacologicum: The Present Status of Psychotropic Drugs, ed. A. Cerletti and F. J. Boré, p. 128. Atatus of Psychotropic Drugs,

\title{
Acute Myocardial Infarction: Home and Hospital Treatment
}

\author{
H. G. MATHER, N. G. PEARSON， K. L. Q. READ， D. B. SHAW， G. R. STEED， M. G. THORNE, \\ S. JONES, C. J. GUERRIER, C. D. ERAUT, P. M. McHUGH, N. R. CHOWDHURY, M. H. JAFARY, \\ T. J. WALLACE
}

British Medical fournal, 1971, 3, 334-338

\section{Summary}

This is a preliminary report of a co-operative study of 1,203 episodes of acute myocardial infarction in men under 70 years in four centres in the south west of England. The mortality at 28 days was $15^{\%}$, A comparison is made between home care by the family doctor and hospital treatment initially in an intensive care unit: 343 cases were allocated at random. The randomized groups do not differ significantly in composition with respect to age; past history of angina, infarction, or hypertension; or hypotension when first examined. The mortality rates of the random groups are similar for home and hospital treatment. The group sent electively to hospital contained a higher proportion of initially hypotensive patients whose prognosis was bad wherever treated; those who were not hypotensive fared rather worse in hospital.

For some patients with acute myocardial infarction seen by their general practitioner home care is ethically justified, and the need for general admission to hospital should be reconsidered.

\section{Introduction}

In the past 20 years there has been a rise in the number of deaths ascribed to coronary heart disease. There has been a corresponding increase of interest in its natural history and

Southmead Hospital, Bristol BS10 5NB

S. JONES, M.B., D.C.H., Research Assistant

C. J. GUERRIER, M.B., M.R.C.P., Research Assistant

H. G. MATHER, M.D., F.R.C.P., Consultant Physician

University of Exeter, Exeter

N. G. PEARSON, M.B., B.S., Co-director, Institute of Biometry and Community Medicine

K. L. Q. READ, PH.D., Lecturer in Mathematical Statistics

Royal Devon and Exeter Hospital, Exeter EX1 1PQ

C. D. ERAUT, M.B., B.CH., Research Assistant

P. M. McHUGH, M.B., B.CH., Research Assistant

D. B. SHAW, M.D., M.R.C.P., Consultant Physician

Scott Hospital, Plymouth PL2 2PQ

G. R. STEED, M.D., F.R.C.P., Consultant Physician

T. J. WALLACE, M.B., M.R.C.P., Research Assistant

Torbay Hospital, Torquay TQ2 7AA

N. R. CHOWDHURY, M.B., B.S., Research Assistant

M. H. JAFARY, M.B., B.S., Research Assistant

M. G. THORNE, M.D., F.R.C.P., Consultant Physician treatment, particularly in those nations where expectation of life is greater than 65 years and where a high proportion of deaths below this age is due to this disease. The value of various drugs, the role of the intensive care unit, and the use of special ambulances have been studied, but little information is available on the fate of patients treated at home except for the reports by Wright (1964), Sleet (1968), Nichols (1968), and Fry (1968).

From a retrospective survey of general practices in the south west of England in 1964, Wright found that patients developing acute myocardial infarction were treated in hospital and at home in about equal numbers and that the mortality rates in the two groups were similar. Accordingly, as one of a number of trials related to coronary care considered by a Ministry of Health working party under the chairmanship of Lord Platt, a randomized controlled trial was planned in order to compare the fate of patients treated in hospital, initially in an intensive care unit, with that of patients treated at home. If, indeed, intensive hospital care offered important advantages then there would be a need (1) to revise the present practice of the family doctor, (2) to plan for increased coronary care facilities and beds in hospital and, (3) perhaps to develop special ambulances in order to shorten the interval between the patient developing pain and receiving intensive care.

\section{Plan of Trial}

The trial was confined to men under 70 years of age who had suffered a myocardial infarction within the previous 48 hours. Women were excluded because it was felt that home care would be difficult for social reasons. The trial was started in Bristol in October 1966, in Exeter in July 1967, in Torbay in January 1968, and in Plymouth in April 1968. Local general practitioners were contacted and over half agreed to participate-altogether 458 .

It was planned that where possible the treatment at home or in hospital would be allocated at random in order to avoid bias in selection. The family doctor carried a sealed envelope stipulating home or hospital care, and the decision on whether a patient could be so selected rested entirely with him. The envelopes were numbered and checked to ensure that the allocation had been adhered to. It was accepted that random selection would not be possible in all patients for the following reasons: (a) social conditions might preclude care being given at home, and patients not resident in the area would not be eligible for randomization; $(b)$ patients suffering an attack at work, in the street, or in hospital would most likely be treated in hospital without reference to the general practitioners; (c) patients or relatives might express a strong desire for home 
or hospital care; and $(d)$ general practitioners might decide that there were medical conditions, which might or might not be associated with the infarction, that precluded random allocation. Therefore, the patients studied fell into four groups.

Elective Hospital.-Patients in this group were those who suffered an attack at work, in the street, on holiday, or in hospital and were admitted without the knowledge of their general practitioners, and those whose general practitioner opted for medical or social reasons, including the patient's wishes, for hospital admission.

Elective Home.-Those whom the general practitioner considered should be cared for at home, again for medical or social reasons or because of the patient's own wishes.

Random Hospital.-Those considered suitable by the general practitioner for random treatment and whose allocation was to hospital intensive care.

Random Home.-Those considered suitable by the general practitioner for random treatment and whose allocation was to home.

\section{CRITERIA FOR ACCEPTANCE}

In this study only patients who fulfilled the following criteria were accepted: clinical evidence suggestive of acute myocardial infarction within the previous 48 hours together with either (a) evolution of World Health Organization (1959) criteria $1 \mathrm{~A}$ (e) (the direct injury current) or 1A (a-d) developing after a normal E.C.G., both obtained during the disease event, or (b) typical $Q$ and $T$ wave changes (W.H.O. Criteria $1 \mathrm{~A}$ a to $1 \mathrm{~B}$. O) in association with a significant rise in the appropriate serum enzyme test (in absence of an irrelevant cause), usually serum lactic dehydrogenase or serum aspartate aminotransferase, or $(c)$ subsequent evidence at necropsy of recent myocardial infarct or recent coronary thrombosis.

The same criteria for entry were required for all centres and for all groups of patients. The diagnosis in the hospital groups was confirmed by investigations in hospital, and in the home groups by visits of a research Fellow to the house where at least three E.C.G.s and two blood tests for serum enzymes were taken. Duplicate reading of E.C.G.s was undertaken between the centres to ensure uniform standards of interpretation and to discuss difficulties. Patients treated at home could later be admitted to hospital if for any reason the doctor felt that this was advisable, though for the purposes of analysis they were retained in their original groups.

\section{DATA STUDIED}

Details of occupation, past medical history, smoking habits, place of onset of the attack, and other clinical details were recorded on standard forms. Time intervals between the presumed onset of the infarct and admission to hospital were recorded at all centres from the inception of the trial; intervals between presumed onset and the first medical examination, however, were recorded at only one centre from the outset (see Appendix) but latterly from all centres. Observations on blood pressure, the signs of heart failure, and abnormal rhythm were recorded. As a minimal requirement examinations were standardized at intervals of one, two, four, and seven days after admission to the trial.

In this preliminary report, which is a study of all patients seen in the four centres up to October 1969, deaths before the arrival of medical aid are excluded, and the data on the patients are confined to the study of age, past history of cardiovascular disease, initial systolic blood pressure, and the mortality at 28 days from the onset of the attack.

\section{TREATMENT}

For those kept at home treatment and the amount of activity allowed were decided by the general practitioner. The random hospital patients were admitted to the intensive care unit usually for a minimum of 48 hours and were otherwise cared for in the adjacent medical ward. Most of the elective hospital group were treated similarly, but a few were admitted to other hospitals and did not necessarily have a period of intensive care.

Intensive care involved continuous observation by trained nursing staff in units adapted or built for the purpose. Oxygen and suction were at the bedside, the E.C.G. was monitored continuously, a D.C. defibrillator was in the unit, and pacing facilities were available. Emphasis was placed on quietness, and every attempt was made to prevent the development of dangerous arrhythmias. There was no standardization of drug treatment for either relief of pain or correction of arrhythmias or treatment of heart failure. Anticoagulants were given at the discretion of the physician in charge. As a general policy if the patient's condition was satisfactory after 48 hours in the unit he was transferred to the adjacent medical ward under the care of the same physician. Most patients were mobile in three weeks and discharged by the end of the fourth week.

\section{Results}

Altogether 1,203 episodes of infarction were studied. A total of $343(28 \%)$ cases were randomly allocated to home or hospital care, $754(63 \%)$ were electively treated in hospital, and 106 $(9 \%)$ were electively treated at home. The high proportion of patients sent to hospital is partly due to the inclusion of those whose attack occurred away from home and those where domestic reasons made home care unsuitable. The age distribution and allocation to treatment groups are shown in Table I. There is no significant* difference in age distribution between groups but there is a slight preponderance of younger subjects treated electively in hospital.

The distribution of patients according to the presence or absence of a known history of cardiovascular disease-that is, angina, myocardial infarction, or hypertension-is given in Table II. There is a slight but not significant tendency for cases with such a past history to concentrate in the elective home group.

TABLE I-Treatment Group and Age

\begin{tabular}{|c|c|c|c|c|c|}
\hline $\begin{array}{c}\text { Age } \\
\text { (years) }\end{array}$ & $\begin{array}{c}\text { Elective } \\
\text { Home }\end{array}$ & $\begin{array}{l}\text { Elective } \\
\text { Hospital }\end{array}$ & $\begin{array}{l}\text { Random } \\
\text { Hospital }\end{array}$ & $\begin{array}{c}\text { Random } \\
\text { Home }\end{array}$ & Total \\
\hline $\begin{array}{l}<50 \\
50-9 \\
60-9 \\
\end{array}$ & $\begin{array}{l}14(13.2 \%) \\
45(42.5 \%) \\
47(44.3 \%)\end{array}$ & $\begin{array}{ll}161 & (21.4 \%) \\
283 & (37.5 \%) \\
310 & (41.1 \%)\end{array}$ & $\begin{array}{l}32(18.9 \%) \\
63(37.3 \%) \\
74(43.8 \%)\end{array}$ & $\begin{array}{l}24(13.8 \%) \\
78(44.8 \%) \\
72(41.4 \%)\end{array}$ & $\begin{array}{ll}231 & (19 \cdot 2 \%) \\
469 & (39 \cdot 1 \%) \\
503 & (41.7 \%)\end{array}$ \\
\hline Total .. & 106 & 754 & 169 & 174 & 1,203 \\
\hline
\end{tabular}
$\chi^{2}$ Calculated between the four treatment groups and the three age groups $=9 \cdot 26$;
not significant.

TABLE II-Treatment Group and Past History of Cardiovascular Disease (C.V.D.) (Angina, Infarction, or Hypertension)

\begin{tabular}{l|c|c|c|c|c}
\hline & $\begin{array}{c}\text { Elective } \\
\text { Home }\end{array}$ & $\begin{array}{c}\text { Elective } \\
\text { Hospital }\end{array}$ & $\begin{array}{c}\text { Random } \\
\text { Hospital }\end{array}$ & $\begin{array}{c}\text { Random } \\
\text { Home }\end{array}$ & Total \\
\hline $\begin{array}{c}\text { History of } \\
\begin{array}{c}\text { C.V.D. } \\
\text { No such } \\
\text { history }\end{array}\end{array}$ & $73(68 \cdot 9 \%)$ & $444(58 \cdot 9 \%)$ & $102(60 \cdot 4 \%)$ & $95(54 \cdot 6 \%)$ & $714(59 \cdot 4 \%)$ \\
Total & 106 & 754 & 169 & 174 & 1,203 \\
\hline
\end{tabular}

$\chi^{2}$ Calculated between the four treatment groups and the presence or absence of $\chi^{2}$ Calculated between the four treatment
a history of C.V.D. $=5 \cdot 75$; not significant.

* "Significant" denotes a significant result of the usual $\chi^{2}$ test at the conventional 5\% level. "Highly significant" denotes significance at the $1 \%$ level "Extremely significant" denotes a value well beyond the range of $\%$ level. statistical tables-that is, significance at a level more stringent than $0 \cdot 1 \%$. 
TABLE II-Initial Systolic Blood Pressure by Treatment Group and Past History of Cardiovascular Disease

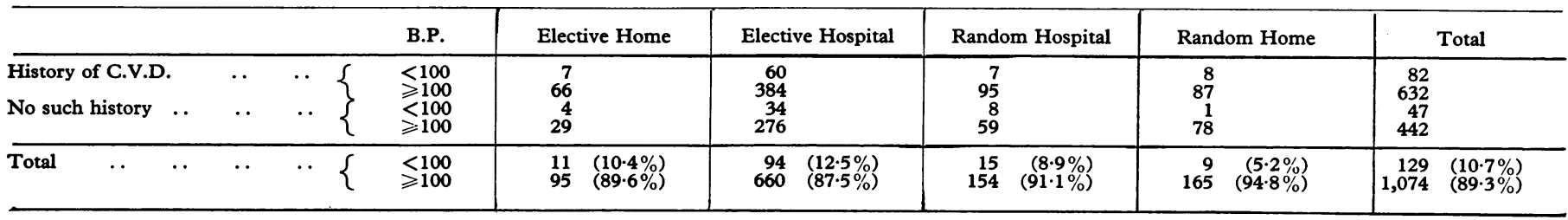

$\chi^{2}$ Calculated between the four treatment groups and presence or absence of initial hypotension (regardless of C.V.D.) $=8 \cdot 61 ;$ significant.

The systolic blood pressure first recorded for the episode is related to the past history and treatment groups in Table III. It is seen that patients with initial hypotension were more numerous in the elective hospital category, particularly among cases with a past history of cardiovascular disease. The total figures are statistically significant.

There were 180 deaths within 28 days in the 1,203 cases studied, giving a death rate of $15 \%$. Mortality by age groups and past history of cardiovascular disease is shown in Table IV. It is seen that mortality increases both with age and with such a history and that the latter is present more often in patients of higher age groups.

The mortality is related to initial systolic blood pressure and time of death in Table V. The mortality was four to five times higher in those patients whose initial systolic blood pressure was less than $100 \mathrm{~mm}$ and death occurred earlier in the illness.

TABLE IV-Mortality at 28 Days by Presence or Absence of Past History of Cardiovascular Disease in Separate Age Groups

\begin{tabular}{c|c|c|c|c|c|c|c|c}
\hline \multirow{2}{*}{} & \multicolumn{2}{|c|}{$<50$ years } & \multicolumn{2}{|c|}{$50-59$ years } & \multicolumn{2}{|c|}{$60-69$ years } & \multicolumn{2}{c}{ Total } \\
\cline { 2 - 8 } & No. & Dead & No. & Dead & No. & Dead & No. & Dead \\
\hline $\begin{array}{c}\text { History } \\
\text { of } \\
\text { C.V.D. }\end{array}$ & 111 & $16(14.4 \%)$ & 285 & $51(17.9 \%)$ & 318 & $69(21.7 \%)$ & 714 & $136(19 \%)$ \\
$\begin{array}{c}\text { No such } \\
\text { history }\end{array}$ & 120 & $2(1.7 \%)$ & 184 & $17(9.2 \%)$ & 185 & $25(13.5 \%)$ & 489 & $44(9 \%)$ \\
Total & 231 & $18(7.8 \%)$ & 469 & $68(14.5 \%)$ & 503 & $94(18.7 \%)$ & 1,203 & $180(15 \%)$ \\
\hline$\chi^{2}$ & 11.32 (H.S.) & \multicolumn{2}{|c|}{$6.76($ H.S.) } & \multicolumn{2}{|c|}{$5.16($ S.) } & \multicolumn{2}{|c|}{$23.2($ H.S.) } \\
\hline
\end{tabular}

In each age group $\chi^{2}$ is calculated between the numbers dead or alive at 28 days and presence or absence of a history of C.V.D.

TABLE v-Mortality and Initial Systolic Blood Pressure

\begin{tabular}{|c|c|c|c|c|c|}
\hline \multirow{2}{*}{ B.P. } & \multicolumn{3}{|c|}{ Time of Death (Days) } & \multirow{2}{*}{$\begin{array}{c}\text { Total } \\
\text { Deaths }\end{array}$} & \multirow{2}{*}{$\begin{array}{c}\text { Total } \\
\text { Patients }\end{array}$} \\
\hline & $<1$ & $2-7$ & $8-28$ & & \\
\hline $\begin{array}{l}\geqslant 100 \\
\geqslant 100\end{array}$ & $\begin{array}{l}21(16.3 \%) \\
20(2 \%)\end{array}$ & $\begin{array}{l}27(20.9 \%) \\
38 \quad(3.5 \%)\end{array}$ & 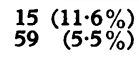 & $\begin{array}{r}63(48 \cdot 8 \%) \\
117(10.9 \%)\end{array}$ & $\begin{array}{r}129 \\
1,074\end{array}$ \\
\hline Total & $41 \quad(3.4 \%)$ & $65 \quad(5 \cdot 4 \%)$ & $74 \quad(6 \cdot 2 \%)$ & $180(15 \%)$ & 1,203 \\
\hline
\end{tabular}

$\chi^{2}$ Calculated between the numbers dead or alive at 28 days and the presence or absence of initial hypotension $=130$; extremely significant.

TABLE VI-Comparison of Treatment Groups by Mortality

\begin{tabular}{c|c|l|l|l|l}
\hline & $\begin{array}{c}\text { Elective } \\
\text { Home }\end{array}$ & $\begin{array}{c}\text { Elective } \\
\text { Hospital }\end{array}$ & $\begin{array}{c}\text { Random } \\
\text { Hospital }\end{array}$ & $\begin{array}{c}\text { Random } \\
\text { Home }\end{array}$ & Total \\
\hline Total Patients & 106 & 754 & 169 & 174 & 1,203 \\
\hline Death <1 day & 1 & 34 & 4 & 2 & 41 \\
" 2-7 days & 5 & 49 & 8 & 3 & 65 \\
8-28 days & 6 & 44 & 12 & 12 & 74 \\
\hline Total deaths & $12(11 \cdot 3 \%)$ & $127(16 \cdot 8 \%)$ & $24(14 \cdot 2 \%)$ & $17(9 \cdot 8 \%)$ & $180(15 \%)$ \\
\hline
\end{tabular}

$\chi^{2}$ Calculated between elective hospital and the other three groups (taken together) are ignored $\chi^{2}=1.64$; not significant.
Comparison of the mortality at 1,7 , and 28 days in the separate treatment groups (Table VI) shows that it was highest in the elective hospital patients. The difference between the total deaths in this group and those in the other groups is statistically significant and is partly due to the large number of deaths occurring on the first day. This difference may be a reflection of the increased frequency of initial hypotension in this group (Table III).

\section{COMPARISONS BETWEEN RANDOM GROUPS}

There are no significant differences in the random groups with regard to either age or past history or frequency of initial hypotension. The randomized groups therefore afford a valid basis for comparison of home and hospital care. There was a $4.4 \%$ lower mortality for those treated at home, the difference arising in the first week. With $95 \%$ confidence we can state that the true difference between the percentage mortalities in the two random groups, and in the circumstances of this trial, lay between $11 \cdot 3 \%$ in favour of home and $2.4 \%$ in favour of hospital treatment.

\section{RESULTS FOR ALL TREATMENT GROUPS}

The mortality in the four treatment groups segregated according to the presence or absence of hypotension is given in Table VII, which shows that the initially hypotensive patients had almost five times the mortality of the non-hypotensives. The mortality of the hypotensive patients is consistent in the four groups, but in the non-hypotensive patients it is significantly higher in the hospital groups compared with the two home groups combined. The random groups share in this contrast but not to a statistically significant degree.

Of the 280 patients treated at home 57 were later transferred to hospital. These patients have been kept in their original group for the purpose of the analysis. The mortality in these 57 transferred patients was higher than in those retained at home and resembled the main group of elective hospital cases.

Of the 180 patients who died within 28 days necropsy evidence was available for 97 , of whom 85 had been treated in hospital. In all but five of the total number evidence of coronary thrombosis/infarction was positively identified; in the remainder severe coronary atheroma was found.

\section{Discussion}

There were no significant differences between the two random groups with regard to any of the characteristics recorded. The group treated at home included somewhat fewer young patients and patients with hypotension, but the differences were within chance limits. Thus the randomization seems to have been effective. The differences in mortality between these groups when studied as a whole or according to initial blood pressure were not significant. The question of whether the random groups were representative of all the cases must be considered. Inevitably those patients whose attack occurred 
TABLE vII-Comparison of Treatment Group Mortalities According to Initial Blood Pressure

\begin{tabular}{|c|c|c|c|c|c|c|c|c|c|c|}
\hline & & & & & & Elective Home & Elective Hospital & Random Hospital & Random Home & Total \\
\hline 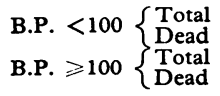 & $\begin{array}{l}\cdots \\
\cdots \\
\cdots\end{array}$ & $\begin{array}{l}\because \\
\because \\
\therefore\end{array}$ & $\begin{array}{l}\cdots \\
\because \\
\cdots\end{array}$ & $\begin{array}{l}\because \\
\because \\
\cdots\end{array}$ & $\begin{array}{l}\because \\
\because \\
\cdots\end{array}$ & $\begin{array}{rr}11 & \\
6 & (54.5 \%) \\
95 & (6.3 \%) \\
6 & (6.3 \%)\end{array}$ & $\begin{aligned} 94 & \\
46 & (48 \cdot 9 \%) \\
660 & (12 \cdot 3 \%)\end{aligned}$ & $\begin{aligned} 15 & \\
7 & (46 \cdot 7 \%) \\
154 & \\
17 & (11 \%)\end{aligned}$ & $\begin{array}{rr}9 & \\
4 & (44.4 \%) \\
165 & (7.9 \%) \\
13 & (7.9 \%\end{array}$ & $\begin{aligned} 129 & \\
63 & (48.8 \%) \\
1,074 & (10.9 \%) \\
117 & (1.9 \%)\end{aligned}$ \\
\hline
\end{tabular}

$\chi^{2}$ Calculated between home and hospital care and the numbers of initially non-hypotensive cases dead or alive at 28 days $=4 \cdot 5 ;$ significant.
$\chi^{2}$ Calculated between the four treatment groups and the numbers of initially hypotensive cases dead or alive at 28 days $=0 \cdot 2 ;$ not significant.

away from their home would be sent to hospital, as would those whose domestic arrangements were unsuitable and some with important medical complications. The random groups comprised subjects whose attack occurred at home and who were first seen by their family doctor. They do, however, typify the clinical problem confronting the general practitioner.

The elective hospital group is the largest and is heterogeneous, comprising patients whose attack occurred in the street, at work, or in hospital; those whose medical or social conditions demanded admission; those who expressed a strong preference for care in hospital; and some who were first seen by a doctor other than their own. The group contains more cases with initial hypotension (Table III); these contribute to the higher death rate in this group as their fate was no better when treated in hospital compared with at home. When the initially nonhypotensive patients are considered separately (Table VII) the hospital groups still fare worse than those treated at home.

It would be inappropriate to deduce from the above figures that domiciliary treatment is preferable in all cases to hospital treatment. Firstly, we have already seen that there was a tendency for patients with hypotension to be sent electively to hospital, and there appears to be no difference between the groups regarding the mortality of this complication. It is noteworthy that this feature, carrying as it so often does the implication of extensive myocardial damage, is one which has proved particularly unresponsive to therapy-even intensive care. It is possible that patients with hypotension also respond especially badly to the stress of a move into hospital. Secondly, it is appreciated that when judging from the figures for hypotension the randomized groups (for whatever reason) contained a larger proportion of the less seriously ill patients. Thirdly, there has been no attempt in this interim analysis to assess in the different groups the incidence of factors such as ectopic beats, arrhythmias, and defects of conduction, which are likely to be amenable to intensive care.

Finally, analysis of the length of time that elapsed between the symptomatic onset of the infarction and the calling of medical help has so far been undertaken only in Bristol (see Appendix). This omission deprives our preliminary report of a further factor for comparison of the random hospital with the elective hospital groups, and between the home and hospital groups in general; for it is known that the fatality rate after myocardial infarction is highest immediately after the incident and falls steeply over the first few hours. It does not, however, detract from the validity of the comparison between the two randomized groups. It must be emphasized that this research was done in an operational setting without publicity to the public or doctors which might influence their normal habits. Moreover the mortality rate compares favourably with that reported from other centres (Lawrie et al., 1967; Lown et al., 1967; Pentecost and Mayne, 1968; Thomas et al., 1968; Norris et al., 1969).

This interim analysis suggests that a randomized comparative trial of the efficiency of domiciliary treatment versus hospital intensive care is a proper and ethical study. It also implies that we should reconsider the grounds on which general practitioners have in the past sought admission of their patients to hospital for medical as distinct from social reasons. The high death rate in the initially hypotensive subjects wherever they are treated might indicate the need for a partial return to the concept of a patient being "too ill to move" if he is hypotensive. Since the initially normotensive patients fare rather better at home (Table VII) it would seem reasonable to keep them there unless complications occur. It may be that multiple ectopic beats, conduction defects, and other dysrrhythmias should prompt early admission to intensive care units which are specifically equipped to deal with such complications. In patients with these complications some form of mobile intensive care may be useful. Yet our observations on mortality raise the question of whether these arrhythmias do not occur more frequently in hospital than at home; even our final report will not answer this direct, as patients are not monitored at home.

Many patients who have suffered a cardiac infarct express a preference for home care because of fear of hospitals or because of a desire to stay with their relatives and to be cared for by their own family doctor. Our findings provide no evidence to suggest that their choice is necessarily mistaken.

We gratefully acknowledge the co-operation of large numbers of general practitioners, without whom this work could not have been done. Professor A. L. Cochrane assisted in the planning of the trial and Dr. G. Ford and Dr. J. M. G. Wilron, of the Department of Health, were of great help in its organization. The expenses were covered by a grant from the Department of Health and Social Security.

\section{Appendix}

The time intervals between the presumed onset of myocardial infarction and first contact with a doctor for the Bristol patients only are given in Table VIII. Altogether $51 \%$ of all cases were seen within four hours of onset, and the proportions seen early did not differ significantly in the four treatment groups. The table indicates the higher mortality within 28 days which

TABLE VIII-Time from Onset of Symptoms to First Contact with Doctor in 615 Cases in Bristol

\begin{tabular}{|c|c|c|c|c|c|c|c|c|}
\hline \multirow{2}{*}{\multicolumn{2}{|c|}{$\begin{array}{l}\text { Delay time } \\
\text { (Hours) }\end{array}$}} & \multirow{2}{*}{ No. } & \multirow{2}{*}{$\begin{array}{c}\% \\
\text { of } \\
\text { Total }\end{array}$} & \multicolumn{4}{|c|}{ Treatment Group } & \multirow{2}{*}{$\begin{array}{c}\text { Died } \\
\text { Within } \\
28 \text { Days }\end{array}$} \\
\hline & & & & $\begin{array}{c}\text { Random } \\
\text { Home }\end{array}$ & $\begin{array}{l}\text { Random } \\
\text { Hospital }\end{array}$ & $\begin{array}{c}\text { Elective } \\
\text { Home }\end{array}$ & $\begin{array}{l}\text { Elective } \\
\text { Hospital }\end{array}$ & \\
\hline $\begin{array}{l}0-1 \quad \ldots \\
1-2 \quad \cdots \\
2-4 \quad \cdots \\
4-12 \quad \cdots \\
12-48 \\
\text { Unknown bu } \\
\leqslant 48\end{array}$ & $\begin{array}{c}. \\
\because \\
\because \\
\ddot{u t} \\
.\end{array}$ & $\begin{array}{r}117 \\
111 \\
84 \\
125 \\
68 \\
110\end{array}$ & $\begin{array}{l}19 \\
18 \\
14 \\
20 \\
11\end{array}$ & $\begin{array}{l}12 \\
10 \\
12 \\
23 \\
12\end{array}$ & $\begin{array}{r}16 \\
16 \\
15 \\
19 \\
11 \\
4\end{array}$ & $\begin{array}{r}17 \\
9 \\
12 \\
19 \\
13 \\
20\end{array}$ & $\begin{array}{l}72 \\
76 \\
45 \\
64 \\
32 \\
85\end{array}$ & $\begin{array}{r}30 \\
21 \\
12 \\
16 \\
5 \\
17\end{array}$ \\
\hline Total & .. & 615 & 100 & 70 & 81 & 90 & 374 & 101 \\
\hline
\end{tabular}

prevails among cases with shorter delay times. Of the 455 patients admitted to hospital only one died between first contact with a doctor and arrival in the intensive care unit. It is therefore evident that at least a modest coverage of the earlier stages in the natural history of the disease has been obtained. 


\section{References}

Fry, J. (1968). Schweizerische medizinische Wochenschrift, 98, 1210

Lawrie, D. M., et al. (1967). Lancet, 2, 109.
Lown, B., Fakhro, A. M., Hood, W. B., jun., and Thorn, W. (1967). fournal of the American Medical Association, 199, 188.
. Nichols, J. B. (1968). Practitioner, 200, 700.

Norris, R. M., Brandt, P. W. T., and Lee, A. J. (1969). Lancet, 1, 278.
Pentecost, B. L., and Mayne, N. M. C. (1968). British Medical Fournal, 1,830 .

Sleet, R. A. (1968). British Medical fournal, 4, 675.

Thomas, M., Jewitt, D. E., and Shillingford, J. P. (1968). British Medical Fournal, 1, 787

World Health Organization (1959). Technical Report Series, No. 168

Wright, H. J. (1964). Unpublished data.

\title{
Resistance of the Breast-fed Infant to Gastroenteritis
}

\author{
CATHERINE L. BULLEN, A. T. WILLIS
}

British Medical fournal, 1971, 3, 338-343

\section{Summary}

From in-vitro studies of breast and cow's milk preparations, and of the faeces from breast-fed and bottle-fed infants, a number of factors seemed likely to influence the production and maintenance of a lactobacillary flora and low pH in the faeces of newborn infants. These were mainly attributable to the nature of the feed. It is suggested that responsible factors in breast milk include its high lactose, low protein, low phosphate content, together with its poor buffering capacity. Importance is also attached to the fact that breast milk seems to provide a fluid feed of small bulk and low residue, and that its use is unlikely to include periods of starvation. Cow's milk, on the other hand, which has a low lactose, high protein, high phosphate content, and a high buffering capacity, is a relatively bulky, high-residue feed. Feeding regimens which employ it are likely to include periods of starvation.

\section{Introduction}

It has been recognized for many years that breast-fed babies are relatively resistant to gastroenteritis (Alexander, 1948; Ross and Dawes, 1954; Hinton and MacGregor, 1958). The continuing incidence of enteropathogenic Escherichia coli infections in young infants, together with the decline in popularity of breast-feeding, led us to a study of this problem. Breast-fed infants differ from bottle-fed infants in two outstanding ways-(1) the microbiological and physicochemical properties of the faeces, and (2) the composition of the feed. Because it seems likely that the first is partly dependent on the second we have carried out some in-vitro studies in an effort to explore this relationship.

The present communication summarizes the findings of this study.

\section{Methods and Results}

\section{INFANT FAECES}

Initial experiments were performed to confirm earlier observations concerning the nature of the bacterial flora and the $\mathrm{pH}$ values of faeces from totally breast-fed and artificially-fed

\footnotetext{
Public Health Laboratory, Luton and Dunstable Hospital, Luton, Beds

CATHERINE L. BULLEN, M.R.C.v.s., Senior Scientist

A. T. WILLIS, M.D., M.R.C.PATH., Director
}

newborn infants. The bottle-fed infants received a variety of commercial dried cow's milk preparations. Ten breast-fed and 21 bottle-fed babies were included in the survey; 9 of these were home deliveries ( 4 breast-fed and 5 bottle-fed infants) and 22 were hospital confinements ( 6 breast-fed and 16 bottle-fed infants). Whenever possible faecal specimens including meconium were collected from birth for the first 28 days of life. In the case of home confinements the first faecal specimen examined was commonly collected towards the end of the first week, whereas in hospital-delivered babies the last specimen was commonly collected on the third or fourth day.

\section{BACTERIAL COUNTS}

Bacterial counts performed by the method of Miles et al. (1938) on faecal specimens commonly showed a relative and absolute numerical preponderance of anaerobic lactobacilli in specimens from breast-fed infants; the highest viable counts of lactobacilli were of the order of $10^{10}$ organisms/g of faeces, in contrast to $E$. coli/coliform counts, which never reached $10^{10}$ organisms $/ g$. Similar counts performed on the faeces of bottle-fed infants showed a reversed situation in which lactobacillus counts did not exceed $10^{8}$ organisms $/ g$, whereas $E$. coli/coliform counts were commonly in excess of $10^{10}$ organisms/g (Figs. 1-3). In the course of these investigations it was noted that the faeces from breast-fed infants never yielded organisms other than anaerobic lactobacilli, bacilli of the $E$. coli/coliform complex, and strains of anaerobic streptococci. Faeces from bottle-fed babies, on the other hand, commonly contained clostridia (notably $\mathrm{Cl}$. welchii and $\mathrm{Cl}$. tertium), Bacteroides and Proteus species, and Pseudomonas aeruginosa.

\section{WATER CONTENT AND PH VALUES}

The water content of faeces from breast-fed infants was always greater than that from bottle-fed babies; average values were $87 \%$ and $74 \%$ respectively (Table I). The pH values of the meconium from all 31 infants fell within the range 5.8-6.5. For the 10 breast-fed infants faecal $\mathrm{pH}$ values fell steadily during the first seven days to a mean value of $5 \cdot 1$. For bottle-fed infants, on the other hand, the mean values rose to $\mathrm{pH} 6.5$ (Fig. 4).

\section{REDUCING AND FERMENTABLE SUBSTANCES}

Reducing substances were detected by Benedict's method in the faeces of breast-fed but not of bottle-fed infants. Fermentation tests with $E$. coli and performed on sterilized emulsions of faeces in sugar-free media failed to show the presence of any fermentable substance in samples from bottle-fed infants. 